\title{
Diversity and Keratin Degrading Ability of Fungi Isolated from Canadian Arctic Marine Bird Feathers
}

\author{
Brent M. Robicheau, ${ }^{1,2}$ Sarah J. Adams, ${ }^{1}$ Jennifer F. Provencher, ${ }^{1,3}$ Gregory J. Robertson, ${ }^{4}$ Mark L. Mallory ${ }^{1,5}$ \\ and Allison K. Walker ${ }^{1,6}$
}

(Received 6 February 2019; accepted in revised form 10 June 2019)

\begin{abstract}
We present the first records of fungi associated with feathers from seabirds and sea ducks in the Canadian Arctic and sub-Arctic. Birds sampled in Nunavut and Newfoundland (Canada) included the Common Eider (Somateria mollissima), King Eider (S. spectabilis), Black-legged Kittiwake (Rissa tridactyla), Northern Fulmar (Fulmarus glacialis), Glaucous Gull (Larus hyperboreus), Black Guillemot (Cepphus grylle), and Thick-billed Murre (Uria lomvia). In total 19 fungal species were cultured from feathers, identified using ITS rDNA barcoding, and screened for their ability to degrade keratin using a keratin azure assay. Our results indicate that 1) of the 19 isolates, $74 \%$ were ascomycetes, while the remaining $26 \%$ were basidiomycetes (yeasts); 2) $21 \%$ of the ascomycete isolates demonstrated keratinolytic activity (a known pathogenicity factor for fungi that may potentially be harmful to birds); 3) the largest number of fungi were cultured from the sampled Thick-billed Murre; and 4) based on a multiple correspondence analysis, there is some indication that both the King Eider and the Thick-billed Murre collected in the low Arctic had distinct fungal communities that were different from each other and from the other birds sampled. Although our sample sizes were small, initial trends in point (4) do demonstrate that additional study is merited to assess whether the fungal community differences are influenced by variation in the known ecologies of the avian hosts and fungi identified.
\end{abstract}

Key words: Arctic; gull; keratin degradation; Newfoundland; Nunavut; seabird

RÉSUMÉ. Nous présentons les premiers enregistrements de champignons se rapportant aux plumes d'oiseaux et de canards de mer dans l'Arctique et la région subarctique du Canada. Parmi les oiseaux échantillonnés au Nunavut et à Terre-Neuve (Canada), notons l'eider à duvet (Somateria mollissima), l'eider à tête grise (S. spectabilis), la mouette tridactyle (Rissa tridactyla), le fulmar boréal (Fulmarus glacialis), le goéland bourgmestre (Larus hyperboreus), le guillemot à miroir (Cepphus grylle) et le guillemot de Brünnich (Uria lomvia). En tout, 19 espèces de champignons ont été prélevées à partir de plumes. Elles ont été identifiées au moyen de codes à barres ITS ADNr et examinées afin de déterminer si elles sont capables de dégrader la kératine, et ce, à l'aide d'une épreuve de dégradation de la kératine au bleu azur. Nos résultats indiquent : 1) que parmi les 19 isolats, $74 \%$ étaient des ascomycètes et que les $26 \%$ restants étaient des basidiomycètes (levures); 2) que $21 \%$ des isolats d'ascomycètes ont affiché une activité kératinolytique (un facteur de pathogénicité pour les champignons, facteur susceptible de nuire aux oiseaux); 3) que le plus grand nombre de cultures de champignons a été prélevé chez le guillemot de Brünnich; et 4) que d'après une analyse de correspondance multiple, il y a une certaine indication que les échantillons de l'eider à tête grise et du guillemot de Brünnich recueillis dans le Bas-Arctique comprenaient des communautés fongiques distinctes qui différaient les unes des autres ainsi que des autres oiseaux échantillonnés. Même si la taille de nos échantillons était petite, les premières tendances ressortant du point (4) démontrent qu'il y a lieu de faire des études plus poussées afin de déterminer si les différences entre les communautés fongiques sont influencées par la variation des écologies connues des hôtes aviaires et des champignons identifiés.

Mots clés : Arctique; mouette; dégradation de la kératine; Terre-Neuve; Nunavut; oiseau de mer

Traduit pour la revue Arctic par Nicole Giguère.

\footnotetext{
${ }^{1}$ Department of Biology, Acadia University, 33 Westwood Ave., Wolfville, Nova Scotia B4P 2R6, Canada

${ }^{2}$ Present address: Department of Biology, Dalhousie University, 1355 Oxford St., Halifax, Nova Scotia B3H 4R2, Canada

${ }^{3}$ Canadian Wildlife Service, Environment and Climate Change Canada, Gatineau, Québec K1A 0H3, Canada

${ }^{4}$ Wildlife Research Division, Environment and Climate Change Canada, Mount Pearl, Newfoundland and Labrador A1N 4T3, Canada

${ }^{5}$ Canada Fulbright Chair in Arctic Studies, University of Washington, Box 353650, Seattle, Washington 98195-3560, USA

${ }^{6}$ Corresponding author: allison.walker@acadiau.ca

(c) The Arctic Institute of North America
} 


\section{INTRODUCTION}

The Canadian Arctic covers 1.4 million $\mathrm{km}^{2}$, the majority of which lies between $60^{\circ}-85^{\circ} \mathrm{N}$ and beyond the tree line (Wilken et al., 2011). Few microfungal diversity studies have been completed in this region, although a major project examined the soil ecology of Devon Island in the Truelove Lowland region as part of the International Biological Programme from 1970-74 (Miller and Laursen, 1974). More recent work includes the identification of endophytes and root mycorrhizae of higher plants in the Arctic, fungi in the active soil layer, moulds and yeasts from Arctic snow and glacial ice, and lichens from Arctic latitudes (e.g., Widden and Parkinson, 1979; Bledsoe et al., 1990; Kohn and Stasovski, 1990; Dalpe and Aiken, 1998; Piercey-Normore, 2005; Butinar et al., 2007; Pietikainen et al., 2007; Ludley and Robinson, 2008). More than 100 fungi have now been documented from the Canadian Arctic. Two recent examples include the novel yeasts Gelidatrema psychrophila and Mrakia arctica (Tsuji et al., 2018a, b). In the circumpolar Arctic, Elvebakk et al. (1996) documented 389 species of fungi from Svalbard (Norway) and Singh and Singh (2012) identified 19 species in 14 genera-including Acremonium, Arthrinium, Aspergillus, Cladosporium, Corynespora, Emericella, Geomyces, Mortierella, Mucor, Myrothecium, Penicillium, Phialophora, Preussia, and Xylaria. Trichosporon dulcitum, Cryptococcus podzolicus, and two Rhodotorula species have also been isolated from dead leaves from the same region (Butinar et al., 2007; Ludley and Robinson, 2008). Collectively, the studies above demonstrate that plant- and soil-associated fungi are found abundantly throughout the Arctic; however, with respect to fungi associated with metazoans, the Canadian Arctic remains largely underexplored.

We conducted a pilot study to document and examine fungi associated with several species of migratory marine birds (colonial seabirds and sea ducks). Animals are known hosts and vectors of fungi (Robinson, 2001), but few studies have determined fungi present on Arctic animals (for examples, see Wojczulanis-Jakubas et al., 2011 and Dynowska et al., 2013). To our knowledge, fungi from Canadian Arctic birds have never been documented. All bird species we examined live near and feed in cold waters of the Arctic or North Atlantic oceans during their breeding season, and most spend the winter along coastal areas or at open sea (Goudie et al., 2000; Gaston et al., 2012). Filamentous fungi and yeasts are known to live on and within the feathers of birds (Pugh, 1965; Singh et al., 2016) where they presumably engage in either a neutral (e.g., hitchhiking), facilitative, and/or exploitive biological interaction. To illustrate this point, fungi can use oils and keratin from feathers for food as commensals, or they may be pathogenic, causing fungal decay of feathers and flesh (Pugh, 1965; Dynowska and Kisicka, 2005a, b). In cold environments, birds also provide a mobile and warmer environment compared to the Arctic surroundings (Dynowska et al., 2013), although many polar fungi are very cold tolerant (e.g., del Frate and Caretta, 1990). Singh et al. (2016) examined the feathers of several Arctic bird species from Svalbard to determine their fungal diversity and the ecological role of fungi isolated from feathers. They documented six species of filamentous fungi and three yeasts, $60 \%$ of which could degrade keratin. Our objectives were to describe the fungal diversity associated with bird feathers from Arctic-breeding migratory birds in eastern Canada and then to test fungi isolated for their potential keratinolytic activity. The latter allowed us to assess any isolate's status as a potential avian pathogen based on its keratinase presence or absence score.

\section{METHODS}

\section{Study Site and Sample Collection}

Birds were sampled from six sites along the cold waters of the Arctic and North Atlantic Oceans within Nunavut and Newfoundland (Canada) (see Table 1 for sampling dates and locations; see also Fig. 1). Monthly temperatures across the sampling range can vary greatly; Cape Vera and Tern Island have an annual mean temperature range of $-36^{\circ} \mathrm{C}$ (February) to $7^{\circ} \mathrm{C}$ (July), whereas Newfoundland ranges from $-9^{\circ} \mathrm{C}$ (February) to $21^{\circ} \mathrm{C}$ (August) (values from http://www.weatherspark.com based on data from Environment Canada).

All marine birds sampled remain in marine habitats for migration and wintering except Glaucous Gulls (Larus hyperboreus), which may spend time ashore at any point of the year (Weiser and Gilchrist, 2012). Additionally, Glaucous Gulls and King Eiders (Somateria spectabilis) and occasionally Common Eiders (S. mollissima) - may fly over land, but all other species remain over water (Powell and Suydam, 2012; Weiser and Gilchrist, 2012). When they return to the breeding colony, female Common Eiders spend 40-50 days around their nests on rocky islands, which may be vegetated with grasses, sedges, and saxifrages (Goudie et al., 2000). King Eiders often nest somewhat inland in vegetation near ponds (Powell and Suydam, 2012). Northern Fulmars (Fulmarus glacialis) and Thick-billed Murres (Uria lomvia) nest on barren rock or pebble ledges. Murres are often found with faeces on their eggs and feet; as well, birds from higher ledges may defecate on nesting birds below (Gaston and Hipfner, 2000; Mallory et al., 2012). Gulls often nest on isolated rock stacks, and both gulls and Black-legged Kittiwakes (Rissa tridactyla) build nests from moss, small sticks, and other vegetation (Hatch et al., 2009; Weiser and Gilchrist, 2012). Black Guillemots (Cepphus grylle) nest in rock crevices on or below cliffs, laying their eggs generally on gravel or bare rock (Butler and Buckley, 2002). Except for the eiders, all other species have bi-parental incubation, meaning parents share approximately $50 \%$ of the incubation and chickrearing time at the nest, the duration of which varies from $40-120$ days. 


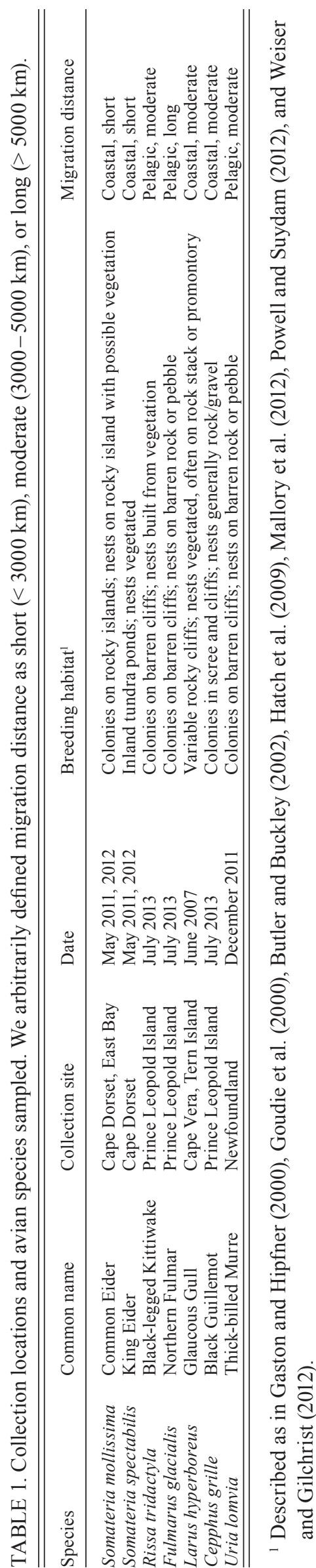

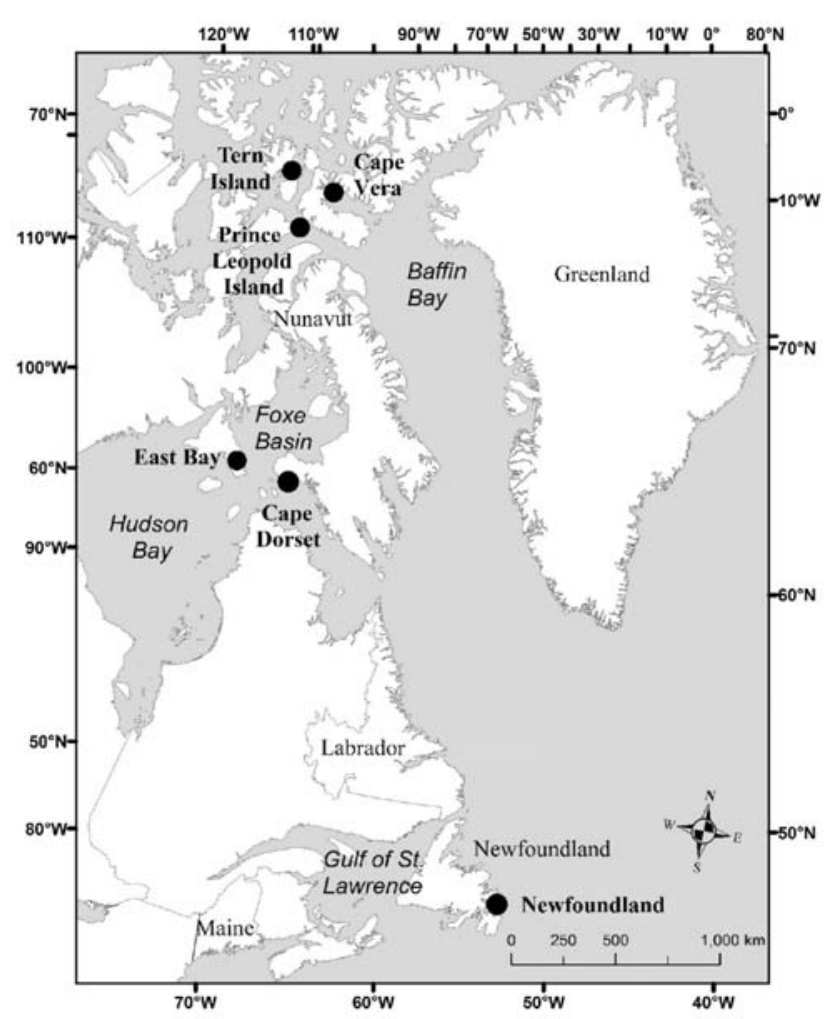

FIG. 1. Location of avian collection sites in the Canadian Arctic.

Most birds were harvested using a 12-gauge shotgun and steel \#2 pellets following methods in Provencher et al. (2016; see also Table 1). Fulmars and Black-legged Kittiwakes were captured at their nests by noose pole and killed humanely on site. Due to the nature of conducting research at a remote location, our work with the local Indigenous community, and consequent sampling protocols, sampled eiders may have come into contact with one another. Specimens were placed in individual bags and frozen at $-20^{\circ} \mathrm{C}$ near the collection site (for most, within two hours of collection; for eiders, within 12 hours) and then shipped frozen to the National Wildlife Research Centre in Ottawa, Canada. Individual birds were subsequently thawed and dissected under clean dissection procedures for use in the original studies. However, heads were separated and individually frozen again in sterile plastic bags. Following storage at $-20^{\circ} \mathrm{C}$ for $2-9$ years, heads were shipped to Acadia University (Wolfville, Nova Scotia) and stored at $-20^{\circ} \mathrm{C}$ until mycological sampling on 17 May 2016. It is important to note that although the freezing of samples may have decreased total culturable fungi (e.g., Huseyin et al., 2017), samples were still subjected to the same general regime of freezing and thawing, which is a factor considered to be of special importance in fungal revival post-preservation, relative to low temperature exposure alone (Robinson, 2001).

\section{Fungal Isolations and Identifications}

One head from each of seven Arctic-breeding species (Common Eider, King Eider, Thick-billed Murre, Black-legged Kittiwake, Glaucous Gull, Black Guillemot, and Northern Fulmar) was retrieved from $-20^{\circ} \mathrm{C}$ storage and kept on ice. Feathers were obtained from the cheeks of each bird using sterile tweezers and scissors and then transferred into separately labeled, sterile $50 \mathrm{~mL}$ plastic centrifuge tubes. This occurred in a laminar flow hood with no feather tissue coming into contact with ice. Four $100 \times 15 \mathrm{~mm}$ large Petri dishes of Sabouraud dextrose agar (SDA; Ward's Science, Rochester, New York) were used to plate feathers from each bird species. Six barbs (10 mm long) were evenly distributed on the surface of individual SDA plates in 
a laminar flow cabinet using sterile forceps (four plates per bird). Plates were then sealed with Parafilm ${ }^{\circledR}$ and incubated at $10^{\circ} \mathrm{C}$ (i.e., midpoint between $4^{\circ} \mathrm{C}$ and $15^{\circ} \mathrm{C}$ used by Singh et al., 2016) for 64 days ( 9 weeks) and observed daily for fungal growth. SDA is an artificial defined medium used in mycological studies to culture fungi from animal tissues and is comprised of $10 \mathrm{~g} / \mathrm{L}$ of mixed peptic digest of animal tissue and pancreatic digest of casein with $40 \mathrm{~g} / \mathrm{L}$ of dextrose and $15 \mathrm{~g} / \mathrm{L}$ of agar, with a $\mathrm{pH}$ adjusted to $5.6 \pm 0.2$ (Singh et al., 2016).

Morphologically unique colonies were sub-cultured from SDA onto potato dextrose agar (PDA) plates and incubated at $10^{\circ} \mathrm{C}$ to obtain an axenic culture of each fungus. Fungal mycelium was then sampled from each axenic culture for DNA extraction and cryopreservation. Five $5 \mathrm{~mm}^{2}$ agar plugs containing mycelium of each culture were preserved in glycerol $(10 \%$ glycerol for filamentous fungi; $40 \%$ glycerol for yeasts) and deposited in the $-80^{\circ} \mathrm{C}$ laboratory collection of A.K. Walker (Acadia University, Wolfville, Nova Scotia). Two additional $5 \mathrm{~mm}^{2}$ agar plugs were preserved in sterile distilled water at $4^{\circ} \mathrm{C}$ for use in downstream molecular work and in subsequent keratinase testing. DNA was isolated from a single agar plug using an UltraClean ${ }^{\circledR}$ Microbial DNA isolation kit following the manufacturer's protocol (QIAGEN Inc. Carlsbad, California). DNA was amplified using polymerase chain reaction (PCR) and the primer set ITS4/ITS5, which is specific to the Internal Transcribed Spacer (ITS) region of fungal ribosomal DNA (White et al., 1990). The ITS region is the recognized DNA barcode region for fungi (Schoch et al., 2012). For filamentous fungal cultures, the PCR reactions were $12.5 \mu \mathrm{L} 2 \times$ AMRESCO Hot Start Taq Master Mix (VWR International LLC, Mississauga, Ontario), $1 \mu \mathrm{L}$ each of $10 \mu \mathrm{M}$ ITS4 and $10 \mu \mathrm{M}$ ITS5 primers (Thermo Fisher Scientific, Waltham, Massachusetts), 9.5 $\mu \mathrm{L}$ sterile nuclease free water (Thermo Fisher Scientific, Fair Lawn, New Jersey), and $1 \mu \mathrm{L}$ of extracted DNA. The thermocycler parameters were $95^{\circ} \mathrm{C}$ for three minutes, 34 cycles of $95^{\circ} \mathrm{C}$ for one minute, $56^{\circ} \mathrm{C}$ for 45 seconds and $72^{\circ} \mathrm{C}$ for one minute, 30 seconds, followed by $72^{\circ} \mathrm{C}$ for 10 minutes. For yeast cultures, PCRs were setup as $21 \mu \mathrm{L} 2 \times$ AMRESCO Hot Start Taq Master Mix (VWR International LLC), $1 \mu \mathrm{L}$ each of $10 \mu \mathrm{M}$ ITS4 and $10 \mu \mathrm{M}$ ITS5 primers (Thermo Fisher Scientific), $1 \mu \mathrm{L}$ sterile nuclease free water and $1 \mu \mathrm{L}$ of extracted DNA. The thermocycler parameters were $94^{\circ} \mathrm{C}$ for 10 minutes, 35 cycles of $94^{\circ} \mathrm{C}$ for one minute, $55^{\circ} \mathrm{C}$ for one minute, $72^{\circ} \mathrm{C}$ for one minute, followed by $72^{\circ} \mathrm{C}$ for 10 minutes. PCRs were checked for DNA amplification using gel electrophoresis at $100 \mathrm{~V}$ for 30 minutes on $1 \% \mathrm{w} / \mathrm{v}$ agarose gels stained with $3 \mathrm{uL}$ of ethidium bromide. This step also ensured that only one target-sized DNA amplicon was produced per sample. Amplicons were then sent to the Génome Québec Innovation Centre (McGill University, Montréal, Québec) for Sanger sequencing.

Fungi were identified by locally aligning returned ITS barcode sequences to nucleotide sequences in the nucleotide and reference sequence (refseq) databases provided in GenBank by the National Center for Biotechnology Information (NCBI; Benson et al., 2005). The local alignments were built using NCBI's Basic Local Alignment Search Tool (BLAST) (Altschul et al., 1990; Camacho et al., 2009). Species-level identifications for fungal isolates were based on a $97 \%$ pair-wise identity (PI) threshold. For sequences that did not have an alignment with a PI score of $97 \%$ or higher, genus-level identifications were assigned by comparing unknown specimens to type specimen sequences (within refseq) that had the next highest PI scores (typically $>90 \% \mathrm{PI}$ ). Phylogenetic trees were constructed using the neighbour-joining (NJ) method with 1000 bootstrap replicates in the program MEGA v6 (Tamura et al., 2013; individual trees not shown). Based on phylogenetic relationships resolved in NJ trees, unknown samples were assigned to a taxonomic group. Using these final identifications, known ecological roles of each isolated fungal species were further reviewed. Representative ITS rDNA barcode sequences are deposited in GenBank under accession numbers MK049880-MK049898. For illustrative purposes only (to show overall diversity), a condensed NJ tree with 1000 bootstrap replicates was built in MEGA using the final representative sequences (this is the tree topology provided in Fig. 2; Tamura et al., 2013).

\section{Multiple Correspondence Analysis}

We used a multiple correspondence analysis (MCA), a technique that is being increasingly applied in mycological studies (e.g., Mbenoun et al., 2017), to determine patterns in the overall association of fungal isolates with avian hosts. An MCA is a multivariate statistical technique that can be used to create a geometrical representation of nominal (i.e., categorical) data (Barberis et al., 2014), and provides an indicator of an association between samples across a suite of categorical variables (Greenacre and Hastie, 1987; Barberis et al., 2014). In our case, each sample was an avian species, which was scored as present or absent for each of the 19 fungal species we found. A fungal species was categorized as being present in each avian species' feathers when it was found on any of the four plates cultured per individual bird (regardless of whether isolates of a fungal species may represent different strains of the same fungal species). Each individual bird was also scored as a certain bird-species-type. By scoring both bird-species-type and presence or absence of a fungal isolate, we could assess if the presence of a certain fungal isolate corresponded with a particular avian species. Our MCA was conducted in R (R Core Team, 2015) using R packages FactoMineR (Lê et al., 2008), factoextra (Kassambara and Mundt, 2016), and ggplot2 (Wickham, 2009).

\section{Keratinase Assay}

To determine if any of the isolated fungi could degrade keratin, fungi were grown individually on keratin azure media using the following protocol that is slightly modified 
from Ahmad and Malloch (1999) and Scott and Untereiner (2004). Fungal cultures stored at $4^{\circ} \mathrm{C}$ in sterile distilled water were revived on PDA media. After one week of incubation at $21^{\circ} \mathrm{C}$, cultures were aseptically streaked onto basal medium (BM; described below) supplemented with $1 \mathrm{~g} / \mathrm{L}$ D-Glucose, $0.5 \mathrm{~g} / \mathrm{L}$ peptone, and $0.5 \mathrm{~g} / \mathrm{L}$ yeast extract. The $\mathrm{pH}$ was adjusted to 9.0 with $6 \mathrm{M}$ sodium hydroxide. BM was prepared by adding $15 \mathrm{~g}$ of agar to $100 \mathrm{~mL}$ of the following solutions (named Solutions \#1-3) for a final volume of 1 L. Solution \#1 contained major salts and consisted of $5 \mathrm{~g}$ $\mathrm{KCl}, 5 \mathrm{~g} \mathrm{MgSO}_{4} \cdot 7 \mathrm{H}_{2} \mathrm{O}$, and $0.01 \mathrm{~g} \mathrm{CaCl}_{2} \cdot 2 \mathrm{H}_{2} \mathrm{O}$ in $1 \mathrm{~L}$ of distilled water. Solution \#2 was a buffer consisting of $6.06 \mathrm{~g}$ of Tris in $1 \mathrm{~L}$ of distilled water and adjusted to $\mathrm{pH}$ 7.6 with concentrated $12 \mathrm{M} \mathrm{HCl}$. Solution \#3 contained micronutrients and consisted of the following combined to a final volume of $1 \mathrm{~L}: 40 \mathrm{~g} \mathrm{NaH}_{2} \mathrm{PO}_{4} \cdot \mathrm{H}_{2} \mathrm{O}, 20 \mathrm{~g} \mathrm{FeCl}_{3} \cdot 6 \mathrm{H}_{2} \mathrm{O}$, and $1 \mathrm{~mL}$ of a solution that had been prepared separately to a final volume of $1 \mathrm{~L}$ containing $1000 \mathrm{mg} / \mathrm{L} \mathrm{MnCl}_{2} \bullet 4 \mathrm{H}_{2} \mathrm{O}$, $1000 \mathrm{mg} / \mathrm{L} \mathrm{ZnSO}_{4} \cdot 7 \mathrm{H}_{2} \mathrm{O}, 100 \mathrm{mg} / \mathrm{L} \mathrm{Na} \mathrm{NoO}_{2} \cdot 2 \mathrm{H}_{2} \mathrm{O}$, and $250 \mathrm{mg} / \mathrm{L} \mathrm{CuSO}_{4} \cdot 5 \mathrm{H}_{2} \mathrm{O}$. Note that Solution \#3 created a milky precipitate and had to be shaken to a homogeneous mixture prior to use. BM was adjusted to $\mathrm{pH} 9$ with $6 \mathrm{M}$ $\mathrm{NaOH}$ prior to use (Ahmad and Malloch, 1999; Scott and Untereiner, 2004).

To test for keratin degradation, $15 \mathrm{~mL}$ of non-amended BM was dispensed into $14 \mathrm{~cm}$ long, flat-bottomed, $30 \mathrm{~mL}$ test tubes, which were then autoclaved and allowed to solidify upright. A $1 \mathrm{~mL}$ mixture of autoclaved BM amended with $4 \mathrm{mg} \mathrm{m} / \mathrm{L}$ of finely chopped keratin azure (Sigma-Aldrich St. Louis, Missouri) was then aseptically overlaid onto the bottom layer of non-amended BM using an autoclaved $10 \mathrm{~mL}$ glass pipette (Ahmad and Malloch, 1999; Scott and Untereiner, 2004). Fungal isolates that were revived on PDA and then transferred to glucose/peptone/ yeast extract amended BM were further transferred to individual keratin azure test tubes by creating consistently sized disks using autoclaved, wide-bore, $1000 \mu \mathrm{L}$ pipette tips attached to $1 \mathrm{~mL}$ sterile syringes. Each fungus was grown in triplicate and incubated at $21^{\circ} \mathrm{C}$ in darkness for six weeks. Tubes were visually assessed for the degradation of keratin by comparing inoculated tubes to non-inoculated tubes in ambient daylight every two days (online Appendix 1). The release of blue azure dye from degraded keratin into the colorless bottom BM layer was interpreted as a positive score for the production of the keratinase enzyme (Ahmad and Malloch, 1999; Scott and Untereiner, 2004).

\section{RESULTS}

\section{Diversity and Known Fungal Ecologies}

We cultured 19 fungal isolates from avian cheek feathers (14 filamentous ascomycetes [74\%] and 5 basidiomycete yeasts [26\%]), with all birds sampled having at least two or more culturable fungi (Fig. 2). The avian species with the most fungal isolates was the Thick-billed Murre with eight different fungal taxa (Fig. 2). There were nine fungal taxonomic classes represented in the final isolate dataset, with each class having more than one fungal isolate except for the Exobasidiomycetes, Agaricomycetes, and Cystobasidiomycetes (Fig. 2). Eurotiomycetes were the most frequently recovered fungal taxonomic class with five different recovered fungal isolate species (Fig. 2). This class also had one of the two isolate species with the highest frequency of recovery among birds, Penicillium antarcticum - which was observed in four of seven of the sampled birds (Fig. 2). In general, most of the fungi isolated (74\%) were only present on one of the birds studied (Fig. 2).

Table 2 provides a summary of the known ecologies for each of the fungal species we identified. Some species represent ubiquitous saprobes known from soil and plant substrates, while others are cold-adapted keratinolytic taxa. Furthermore, several isolates are also known from polar marine environments. In reviewing the known literature for these taxa, to the best of our knowledge 17 of the species (89\%) represent new records for the Canadian Arctic (all isolates except Penicillium decumbens [Dalpe and Aiken, 1998] and Pseudogymnoascus pannorum [Widden and Parkinson, 1979]; Table 2).

\section{Keratinase Activity}

Following culturing, each of the different isolates were individually assessed for potential keratinolytic activity. The fungal species showing keratinolytic ability were Pseudogymnoascus pannorum, Cadophora malorum, and Neosetophoma samarorum, which were only found on the two eider species. Cadophora malorum and Neosetophoma samarorum also had a seemingly stronger keratinase activity based on the intensity in which the keratin azure dye was released into BM during the assay, as well as the number of triplicate tubes in the assay that scored positive (online Appendix 1). The three species with keratinolytic activity were all ascomycetes, representing $21 \%$ of the ascomycetes recovered, and two out of three belong to the class Leotiomycetes (Fig. 2).

\section{Multiple Correspondence Analysis}

The first two dimensions of our MCA explained 56\% of the total variance in our dataset (Fig. 3), with the first dimension explaining $33 \%$ of the variance and the second $23 \%$. These two dimensions showed a clear separation between Thick-billed Murre, King Eider, and the other five bird species. The murre was mainly differentiated along the first dimension and was associated with the presence of isolates Aspergillus pseudoglaucus, Holtermanniella wattica, Penicillium chrysogenum, Penicillium decumbens, Peniophora cinerea, and a Saccharomyces hybrid (isolate codes $=\mathrm{X} 1, \mathrm{X} 8, \mathrm{X} 12, \mathrm{X} 13, \mathrm{X} 15$, and $\mathrm{X} 17$, respectively; Figs. 2 and 3). King Eider was differentiated along the second dimension and was associated with the presence 


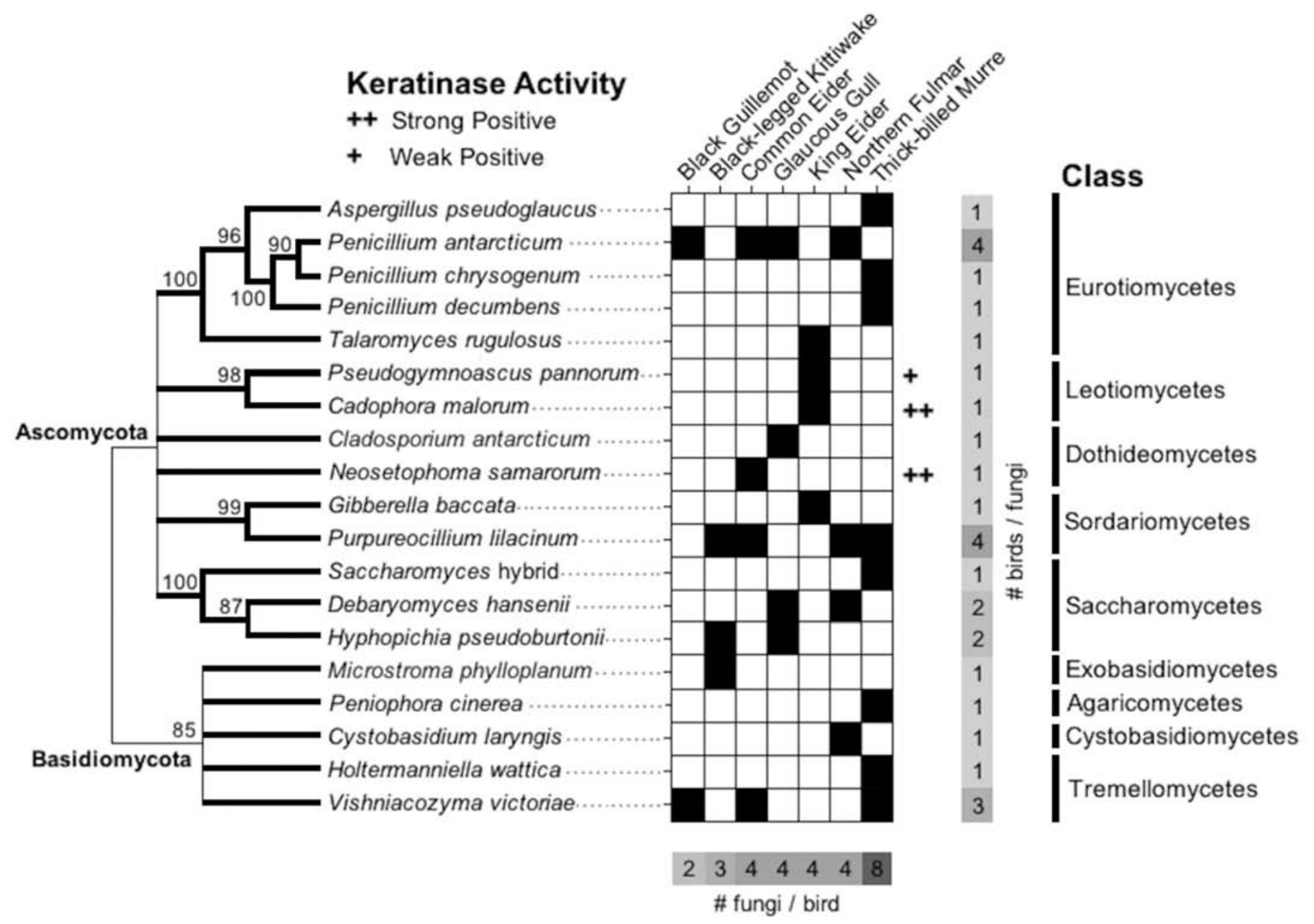

FIG. 2. Diversity and keratinase activity of fungi associated with Canadian Arctic bird feathers.

of Cadophora malorum, Pseudogymnoascus pannorum, Gibberella baccata, and Talaromyces rugulosus (isolate codes $=$ X2, X6, X7, X18, respectively; Figs. 2 and 3). The remainder of the bird species and fungal isolates were more associated with each other and clustered away from those fungi associated with the King Eider and the Thick-billed Murre (Fig. 3). Overall, the MCA indicated that the Thickbilled Murre and King Eider had unique culturable fungal communities, while all other birds sampled had culturable fungal communities distinct from the Thick-billed Murre and King Eider, but similar to one another.

\section{DISCUSSION}

The majority of fungi we cultured-17 of the 19 fungi, or $89 \%$ - represent new records for the Canadian Arctic. Regarding previously known avian associations, three genera we cultured are known from Svalbard (Norway) bird feathers: Aspergillus, Cladosporium, and Penicillium (Singh et al., 2016). Penicillium was the most frequently isolated genus and it also fell within the most cultured taxonomic class: Eurotiomycetes. Specifically, five out of seven birds $(71 \%)$ had one or more species of Penicillium, with three of our four Penicillium antarcticum isolates (the most frequently recovered isolate) matching the Rorvig Penicillium antarcticum strain CBS 116939 (McRae et al., 1999). Observing Penicillium species in our samples was not surprising given that a mycobiota survey by Sonjak et al. (2006) resulted in $25 \%$ of their cultures being Penicillium. Since Penicillium is a cosmopolitan fungal genus that is ubiquitous in Arctic environments (Sonjak et al., 2006; Henk et al., 2011), we expected that there would be numerous opportunities for spores to contact avian hosts; that is, fungal spores were likely acquired from the avian habitat prior to collection. For instance, over half of the fungi observed have been previously recorded from soils, while others are known from marine and plant sources (e.g., mosses; see Table 2 for more detailed fungal ecology descriptions).

Given that the ecology of the fungal isolates seemed to largely reflect host-to-substrate contact, what is perhaps more interesting is how the fungi observed differed among the various bird hosts. While we acknowledge that our pilot study only relied on one bird to represent each species, our MCA demonstrated that the isolates could be divided into distinct fungal assemblages. These included unique fungal communities on each of the Thick-billed Murre and 
TABLE 2. Known ecologies of fungi isolated from Canadian Arctic seabirds and sea ducks.

\begin{tabular}{|c|c|c|}
\hline Isolate & Identification & Literature and references \\
\hline 1 & Aspergillus pseudoglaucus & $\begin{array}{l}\text { A fermentation agent in various Asian foods (e.g., meju and katsuobushi; Hong et al., 2015). Found in urban water } \\
\text { samples (Kadaifciler et al., 2013). }\end{array}$ \\
\hline 2 & Cadophora malorum & $\begin{array}{l}\text { Previously isolated from Antarctic mosses (Tosi et al., 2002) and wooden structures of Antarctica } \\
\text { (Held and Blanchette, 2017). Pathogen of woody plants (e.g., oak, spruce, and beech; Marco et al., 2004). }\end{array}$ \\
\hline 3 & Cladosporium antarcticum & $\begin{array}{l}\text { Genus includes various halophilic fungi, and species of this genus are often found in marine environments } \\
\text { (Zalar et al., 2007). Was previously isolated and first described from a lichen collected in Antarctica } \\
\text { (Schubert et al., 2007). }\end{array}$ \\
\hline 4 & Cystobasidium laryngis & $\begin{array}{l}\text { Known as an Antarctic angiosperm endophyte occurring in the leaves of Antarctic hair grass } \\
\text { (Deschampsia antarctica) (Santiago et al., 2017). }\end{array}$ \\
\hline 5 & Debaryomyces hansenii & $\begin{array}{l}\text { Salt-tolerant fungus (Adler et al., 1985) that is used in the biocontrol of both blue and green rot of citrus } \\
\text { (Droby et al., 1989). }\end{array}$ \\
\hline 6 & Pseudogymnoascus pannorum & Commonly found in soils of colder regions and is a cold-adapted fungus (Zhang et al., 2016). \\
\hline 7 & Gibberella baccata & $\begin{array}{l}\text { Found globally and is a known pathogen of woody plants (Lawrence et al., 1985). Has been isolated from South } \\
\text { African soil (Desjardins, 2003). }\end{array}$ \\
\hline 8 & Holtermanniella wattica & Soil yeast isolated from Patagonian forests (Mestre et al., 2014). \\
\hline 9 & Hyphopichia pseudoburtonii & $\begin{array}{l}\text { Known pathogen originally isolated from the rumen content of animals (Groenewald and Smith, 2010; } \\
\text { Limtong et al., 2012; Nikolajeva et al., 2015). }\end{array}$ \\
\hline 10 & Microstroma phylloplanum & Genus previously isolated from the surface of plums (Janisiewicz et al., 2014). \\
\hline 11 & Neosetophoma samarorum & Known from shoots of Norway spruce (Menkis et al., 2015) and from deep-sea sediments (Zhang et al., 2014). \\
\hline 12 & Penicillium chrysogenum & A globally distributed fungus (e.g., in Antarctica) that was central to the discovery of penicillin (Henk et al., 2011). \\
\hline 13 & Penicillium decumbens & $\begin{array}{l}\text { Produces the plant cell-wall degrading enzyme cellulase and also has a high transglycosylation activity } \\
\text { (Chen et al., 2011). Previously isolated from deteriorating straw-covered soil (Sun et al., 2008; Liu et al., 2013). }\end{array}$ \\
\hline 14 & Penicillium antarcticum & $\begin{array}{l}\text { Previously found in soil, Antarctic moss, marine environments, and nest scrapings (McRae et al., 1999; } \\
\text { Park et al., 2014). }\end{array}$ \\
\hline 15 & Peniophora cinerea & $\begin{array}{l}\text { A ligninolytic fungus (Okamoto et al., 2010); has been found in peat lands from the White Sea coast in Russia } \\
\text { (Grum-Grzhimaylo et al., 2016). }\end{array}$ \\
\hline 16 & Purpureocillium lilacinum & Cosmopolitan saprobe found from nematodes, humans, soils, and insects (Luangsa-ard et al., 2011). \\
\hline 17 & Saccharomyces hybrid & $\begin{array}{l}\text { A hybrid of } S \text {. cerevisiae } \times \text { S. eubayanus } \times S \text {. uvarum. Such hybrids of Saccharomyces are common in the } \\
\text { domestication of yeasts for wine and beer fermentation (Libkind et al., 2011; Peris et al., 2014). }\end{array}$ \\
\hline 18 & Talaromyces rugulosus & $\begin{array}{l}\text { Generates the enzymes phosphatase and } \beta \text {-rutinosidase, as well as the compounds skyrin and rugulosin } \\
\text { (Yilmaz et al., 2014). Known from sandy fynbos soil (Visagie and Jacobs, 2012). }\end{array}$ \\
\hline 19 & Vishniacozyma victoriae & Abundant in the soil and litter of temperate forest habitats (Mašínová et al., 2017). \\
\hline
\end{tabular}

the King Eider. Based on the results of this pilot study, we suggest three hypotheses for further research on fungiavian host relationships in the Arctic: 1) that variation in fungal community may be linked to host breeding habitat preference, 2) that variation may be linked to marine habitat preference, and 3) that variation may be linked to whether fungi observed are commensals or pathogenic. In future, the role of habitat location-breeding or marine and high Arctic versus low Arctic-should be considered when thinking about how habitat-related trends arise.

We suspect that our initial results support a role for differential breeding habitats on fungi-avian host variation. For example, Thick-billed Murres spend much of their breeding season resting in faeces or being splattered with faeces from birds nesting on ledges above them (Gaston and Hipfner, 2000). This nitrogen-rich, acidic environment may support a different fungal assemblage than that of other cliff-nesting species, whose nests are bare, clean rock, or are built from local moss. Likewise, the King Eider mycobiota included fungi associated with woody plants. Their inland habitats - on tundra and around freshwater ponds (Powell and Suydam, 2012) - are the only nesting sites that would support much woody vegetation (principally Betula and Salix shrubs). This interpretation is consistent with the expectation that some of the fungi are from the local terrestrial Arctic environment and not endemic to bird feathers. The remainder of the hosts had relatively similar fungal communities (albeit some apparent differences, e.g., kittiwake), and generally nested in similar substrates consisting of rocks, mosses, and lichens.

Similarly, differences in marine habitat use by the bird species could play a role in the fungal communities present on feathers. Hassett et al. (2016) suggested that differences in fungal communities are expected due to the high levels of environmental selection likely experienced by fungi in Arctic marine environments, and that there is an underlying, understudied variation in fungal diversity in Arctic marine waters. Among the bird species we studied, eiders (both species), gulls, and guillemots use primarily coastal, nearshore, shallow marine habitats during the breeding season, whereas kittiwakes, fulmars, and murres use deeper, offshore pelagic regions-with murres diving to depths of $150 \mathrm{~m}$ (Gaston and Hipfner, 2000). Such habitat usage patterns are also reflected in differences in their trophic niches and contaminant profiles (e.g., Mallory and Braune, 2012). In the future it would be useful to characterize fungi from water samples.

Further, feather fungal community composition may be influenced by potential biological interactions between fungi and avian hosts; some fungi may be commensal or pathogenic. For example, two of our isolates, Cadophora malorum and Hyphopichia pseudoburtonii, can be pathogenic (Di Marco et al., 2004; Groenewald and Smith, 2010; Limtong et al., 2012; Nikolajeva et al., 2015; Table 2), while three other isolates demonstrated keratinolytic activity (Pseudogymnoascus pannorum, Cadophora 


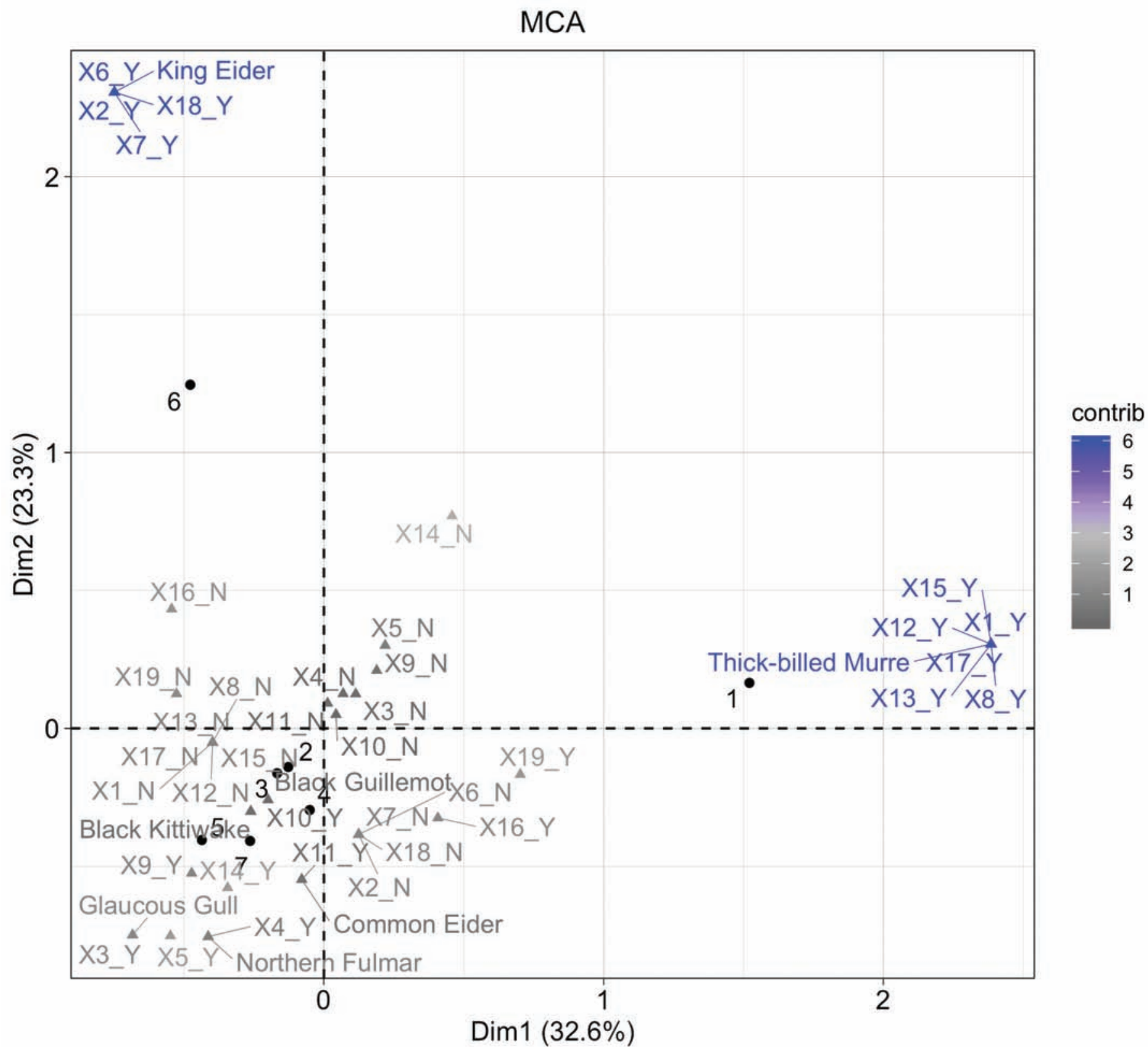

FIG. 3. Multiple correspondence analysis of fungal isolates and Arctic bird species plotted in the first two dimensions. Individual birds are represented by black numbered circles. Variables (triangles) were categorized as either a particular bird-type (i.e., avian name), or alternatively, presence "Y" or absence " $\mathrm{N}$ " for each fungal isolate number. Labels "X\#" refer to the fungal isolate number from Table 2. Variable categories were shaded blue according to their contribution to the first two dimensions labelled "contrib" (i.e., higher contributions = blue: lower contributions = gray).

malorum, and Neosetophoma samarorum), suggesting that they could use keratin as a carbon source (Pugh, 1965; Fig. 2) and therefore should be considered candidates for being potential avian pathogens. It is important to note that these fungi could have made use of their keratin-degrading ability as a means of living on the bird and not simply being transferred to the host from habitat substrate.

The psychrophilic fungus Pseudogymnoascus pannorum that we isolated is a known keratinophilic species (Out et al., 2016). It is a ubiquitous saprophytic fungus frequently isolated from soil and air samples and has rarely been reported as an animal or plant pathogen, but is an occasional causal agent of superficial infection of skin and nails in humans (e.g., Gianni et al., 2003). In contrast, Cadophora malorum and Neosetophoma samarorum have not previously been documented as keratinolytic. Our ability to score these two fungi as keratinolytic is not entirely surprising given that keratinolytic fungi are known from keratin-containing animal remains in polar soils (e.g., del Frate and Caretta, 1990). Interestingly, a pre-existing avian cholera (Pasteurella multocida) outbreak affected the sampled Common Eider population (Descamps et al., 2009) and this eider species supported one of the strongly keratinolytic fungi (Neosetophoma samarorum) revealed in our assay. Keratinolytic ability is a known pathogenicity factor in fungi (Kaul and Sumbali, 1999; Filipello 
Marchisio et al., 2000); further studies should assess whether the presence of keratinolytic fungi on the sampled Common Eider is reflective of population health status at the time of sampling.

Since our study tested fungi isolated from bird feathers and our assay used wool as a keratin source, it is conceivable that the ability to degrade feather keratin may not have been accurately represented in the event that feather structures respond differently than sheep's wool-based keratin azure when exposed to keratinase. Nevertheless, to degrade sheep keratin in our assay, the fungal isolates must have had the ability to produce keratinases (Scott and Untereiner, 2004). In light of this, we can still label P. pannorum, $C$. malorum, and $N$. samarorum as potential fungal pathogens; however, further genomic investigation would be helpful in determining if any additional pathogenicity factors are present in the isolates we found.

Some of the fungal species found on these Arctic birds are also found on birds in the Antarctic (e.g., Penicillium spp.; McRae et al., 1999), meaning that the fungi are either distributed pole to pole naturally by atmospheric or ocean currents or that birds have transported these among populations. Although an in-depth review of spore longevity goes beyond the scope of this project, this sort of inquiry regarding animal- (perhaps even human-) vectored microorganisms into polar environments is certainly interesting (e.g., Cerdà-Cuéllar et al., 2019). For fungi specifically, previous work does give some insight into spore survival times. Under optimal conditions, fungal spores may survive months (e.g., basidiomycete spores) to several years (e.g., some Penicillium spp.; Rintala et al., 2012). Although it is tempting to think that birds may act as important pole-to-pole vectors for fungi, at present it is difficult to know whether the birds we studied acquired fungi over a short or long timeframe. In this regard, more latitudinal work is required.

\section{CONCLUSIONS}

We present the first records of filamentous fungi and yeasts associated with Canadian Arctic marine birds (14 ascomycetes and 5 basidiomycetes), with $21 \%$ of the ascomycetes displaying keratinolytic activity (a known pathogenicity factor for fungi that may or may not be harmful to avian species). We interpret assemblages in our MCA to imply that breeding habitat may play an important role in shaping the external fungal community of Canadian Arctic marine birds, and our data establish a baseline for the culturable fraction of Canadian Arctic avian mycobiota. We recommend that future research include fungal community sequencing of bird feathers and their marine habitats, as well as controlled studies of spore dispersal by long distance avian migrants. With the anticipated northward expansion of pathogens (Marcogliese, 2008; van der Putten et al., 2010) and the fact that the Arctic region is warming at a faster rate than much of the rest of the globe, it is imperative to document host-fungal relationships and determine fungal species capable of displaying fungal pathogenicity factors (e.g., keratinase production).

\section{ACKNOWLEDGEMENTS}

We thank Environment and Climate Change Canada (ECCC) field crews for collecting birds. This work was supported by a Natural Sciences and Engineering Research Council (NSERC) Discovery Grant to M.L. Mallory (Grant No. NSERC-12482122017), an NSERC Discovery Grant to A.K. Walker (Grant No. NSERC-2017-04325), a 2017-18 Environment Canada CleanTech Internship to S.J. Adams, a 2016-17 Environmental Careers Organization (ECO) Canada Environmental Youth Corps (EYC) Internship to B.M. Robicheau, and a Weston Foundation Fellowship for Northern Research (via the Association of Canadian Universities for Northern Studies; ACUNS) to J.F. Provencher. Funding sources had no involvement in our study design, data analysis, manuscript preparation, or decision to publish. We thank the Génome Québec Innovation Centre at McGill University for DNA sequencing, and several anonymous referees for comments on the manuscript.

\section{REFERENCES}

Adler, L., Blomberg, A., and Nilsson, A. 1985. Glycerol metabolism and osmoregulation in the salt-tolerant yeast Debaryomyces hansenii. Journal of Bacteriology 162(1):300-306.

Ahmad, I., and Malloch, D. 1999. An evaluation of carbon and nitrogen assimilatory patterns for taxonomic differentiation of Penicillium species. Mycologia 91(6):1031-1044. https://doi.org/10.1080/00275514.1999.12061114

Altschul, S.F., Gish, W., Miller, W., Myers, E.W., and Lipman, D.J. 1990. Basic local alignment search tool. Journal of Molecular Biology 215(3):403-410. https://doi.org/10.1016/S0022-2836(05)80360-2

Barberis, M.G., Giaj Merlera, G., Reynoso, M.M., Chulze, S.N., and Torres, A.M. 2014. Factors affecting distribution and abundance of Aspergillus section Nigri in vineyard soils from grapevine growing regions of Argentina. Journal of Scientific Food and Agriculture 94(14):3001-3007.

https://doi.org/10.1002/jsfa.6647

Benson, D.A., Karsch-Mizrachi, I., Lipman, D.J., Ostell, J., and Wheeler, D.L. 2005. GenBank. Nucleic Acids Research 33(Suppl. 1):D34-D38. https://doi.org/10.1093/nar/gki063

Bledsoe, C., Klein, P., and Bliss, L.C. 1990. A survey of mycorrhizal plants on Truelove Lowland, Devon Island, N.W.T., Canada. Canadian Journal of Botany 68(9):1848 - 1856. https://doi.org/10.1139/b90-242

Butinar, L., Spencer-Martins, I., and Gunde-Cimerman, N. 2007. Yeasts in High Arctic glaciers: The discovery of a new habitat for eukaryotic microorganisms. Antonie van Leeuwenhoek Journal of Microbiology 91(3):277-289.

https://doi.org/10.1007/s10482-006-9117-3 
Butler, R.G., and Buckley, D.E. 2002. Black Guillemot (Cepphus grylle), version 2.0. In: Rodewald, P.G., ed. The birds of North America. Ithaca, New York: Cornell Lab of Ornithology. https://doi.org/10.2173/bna.675

Camacho, C., Coulouris, G., Avagyan, V., Ma, N., Papadopoulos, J., Bealer, K., and Madden, T.L. 2009. BLAST+: Architecture and applications. BMC Bioinformatics 10: 421. https://doi.org/10.1186/1471-2105-10-421

Cerdà-Cuéllar, M., Moré, E., Ayats, T., Aguilera, M., MuñozGonzález, S., Antilles, N., Ryan, P.G., and González-Solís, J. 2019. Do humans spread zoonotic enteric bacteria in Antarctica? Science of the Total Environment 654:190-196. https://doi.org/10.1016/j.scitotenv.2018.10.272

Chen, S., Xing, X.-H., Huang, J.-J., and Xu, M.-S. 2011. Enzymeassisted extraction of flavonoids from Ginkgo biloba leaves: Improvement effect of flavonol transglycosylation catalyzed by Penicillium decumbens cellulase. Enzyme Microbiology and Technology 48(1):100-105.

https://doi.org/10.1016/j.enzmictec.2010.09.017

Dalpé, Y., and Aiken, S.G. 1998. Arbuscular mycorrhizal fungi associated with Festuca species in the Canadian High Arctic. Canadian Journal of Botany 76(11):1930-1938.

https://doi.org/10.1139/b98-165

Del Frate, G., and Caretta, G. 1990. Fungi isolated from Antarctic material. Polar Biology 11(1):1-7. https://doi.org/10.1007/BF00236515

Descamps, S., Gilchrist, H.G., Bêty, J., Buttler, E.I., and Forbes, M.R. 2009. Costs of reproduction in a long-lived bird: Large clutch size is associated with low survival in the presence of a highly virulent disease. Biology Letters 5:278-281. https://doi.org/10.1098/rsbl.2008.0704

Desjardins, A.E. 2003. Gibberella from $A$ (venaceae) to $Z$ (eae). Annual Review of Phytopathology 41:177-198. https://doi.org/10.1146/annurev.phyto.41.011703.115501

Di Marco, S., Calzarano, F., Osti, F., and Mazzullo, A. 2004. Pathogenicity of fungi associated with a decay of kiwifruit. Australasian Plant Pathology 33(3):337-342. https://doi.org/10.1071/AP04024

Droby, S., Chalutz, E., Wilson, C.L., and Wisniewski, M. 1989. Characterization of the biocontrol activity of Debaryomyces hansenii in the control of Penicillium digitatum on grapefruit. Canadian Journal of Microbiology 35(8):794-800.

https://doi.org/10.1139/m89-132

Dynowska, M., and Kisicka, I. 2005a. Fungi isolated from selected birds potentially pathogenic to humans. Acta Mycologia 40(1):141 - 147. https://doi.org/10.5586/am.2005.013

__ _ 2005b. Participation of birds in the circulation of pathogenic fungi descend from water environments: A case study of two species of Charadriiformes birds. International Journal of Ecohydrology and Hydrobiology 5(2):173 - 178.

Dynowska, M., Wojczulanis-Jakubas, K., Pacynska, J.A., Jakubas, D., and Ejdys, E. 2013. Potentially pathogenic yeast isolated from the throat and cloaca of an Arctic colonial seabird: The little auk (Alle alle). Polar Biology 36(3):343-348.

https://doi.org/10.1007/s00300-012-1263-7
Elvebakk, A., Gjaerum, H.B., and Sivertsen, S. 1996. Part 4. Fungi II. Myxomycota, Oomycota, Chytridiomycota, Zygomycota, Ascomycota, Deuteromycota, Basidiomycota: Uredinales and Ustilaginales. In: Elvebakk, A., and Prestrud, P., eds. A catalogue of Svalbard plants, fungi, algae and cyanobacteria. Skrifter nr. 198. Oslo: Norsk Polarinstitutt. 207-259.

Filipello Marchisio, V., Fusconi, A., and Querio, F.L. 2000. Scopulariopsis brevicaulis: A keratinophilic or a keratinolytic fungus? Mycoses 43(7-8):281 - 292. https://doi.org/10.1046/j.1439-0507.2000.00580.x

Gaston, A.J., and Hipfner, J.M. 2000. Thick-billed Murre (Uria lomvia), version 2.0. In: Rodewald, P.G., ed. The birds of North America. Ithaca, New York: Cornell Lab of Ornithology. https://doi.org/10.2173/bna.497

Gaston, A.J., Mallory, M.L., and Gilchrist, H.G. 2012. Populations and trends of Canadian Arctic seabirds. Polar Biology 35(8):1221-1232.

https://doi.org/10.1007/s00300-012-1168-5

Gianni, C., Caretta, G., and Romano, C. 2003. Skin infection due to Geomyces pannorum var. pannorum. Mycoses 46(910):430-432. https://doi.org/10.1046/j.1439-0507.2003.00897.x

Goudie, R.I., Robertson, G.J., and Reed, A. 2000. Common Eider (Somateria mollissima), version 2.0. In: Rodewald, P.G., ed. The birds of North America. Ithaca, New York: Cornell Lab of Ornithology. https://doi.org/10.2173/bna.546

Greenacre, M., and Hastie, T. 1987. The geometric interpretation of correspondence analysis. Journal of the American Statistical Association 82(398):437-447.

https://doi.org/10.1080/01621459.1987.10478446

Groenewald, M., and Smith, M.T. 2010. Re-examination of strains formerly assigned to Hyphopichia burtonii, the phylogeny of the genus Hyphopichia, and the description of Hyphopichia pseudoburtonii sp. nov. International Journal of Systematic and Evolutionary Microbiology 60(11):2675-2680. https://doi.org/10.1099/ijs.0.018580-0

Grum-Grzhimaylo, O.A., Debets, A.J.M., and Bilanenko, E.N. 2016. The diversity of microfungi in peatlands originated from the White Sea. Mycologia 108(2):233-254.

https://doi.org/10.3852/14-346

Hassett, B.T., Ducluzeau, A.L.L., Collins, R.E., and Gradinger, R. 2016. Spatial distribution of aquatic marine fungi across the western Arctic and sub-Arctic. Environmental Microbiology 19(2):475-484. https://doi.org/10.1111/1462-2920.13371

Hatch, S.A., Robertson, G.J., and Baird, P.H. 2009. Black-legged Kittiwake (Rissa tridactyla), version 2.0. In: Rodewald, P.G., ed. The birds of North America. Ithaca, New York: Cornell Lab of Ornithology. https://doi.org/10.2173/bna.92

Held, B.W., and Blanchette, R.A. 2017. Deception Island, Antarctica, harbors a diverse assemblage of wood decay fungi. Fungal Biology 121(2):145-157.

https://doi.org/10.1016/j.funbio.2016.11.009 
Henk, D.A., Eagle, C.E., Brown, K., van den Berg, M.A., Dyer, P.S., Peterson, S.W., and Fisher, M.C. 2011. Speciation despite globally overlapping distributions in Penicillium chrysogenum: The population genetics of Alexander Fleming's lucky fungus. Molecular Ecology 20(20):4288 - 4301. https://doi.org/10.1111/j.1365-294X.2011.05244.x

Hong, S.-B., Kim, D.-H., and Samson, R.A. 2015. Aspergillus associated with $M e j u$, a fermented soybean starting material for traditional soy sauce and soybean paste in Korea. Mycobiology 43(3):218-224. https://doi.org/10.5941/MYCO.2015.43.3.218

Huseyin, C.E., Rubio, R.C., O'Sullivan, O., Cotter, P.D., and Scanlan, P.D. 2017. The fungal frontier: A comparative analysis of methods used in the study of the human gut mycobiome. Frontiers in Microbiology 8: 1432. https://doi.org/10.3389/fmicb.2017.01432

Janisiewicz, W.J., Jurick, W.M., II, Peter, K.A., Kurtzman, C.P., and Buyer, J.S. 2014. Yeasts associated with plums and their potential for controlling brown rot after harvest. Yeast 31(6):207-218. https://doi.org/10.1002/yea.3009

Kadaifciler, D.G., Ökten, S., and Sen, B. 2013. Mycological contamination in dental unit waterlines in Istanbul, Turkey. Brazilian Journal of Microbiology 44(3):977-981. https://doi.org/10.1590/S1517-83822013000300049

Kassambara, A., and Mundt, F. 2016. factoextra: Extract and visualize the results of multivariate data analyses. $\mathrm{R}$ package version 1.0.3.

https://CRAN.R-project.org/package=factoextra

Kaul, S., and Sumbali, G. 1999. Production of extracellular keratinases by keratinophilic fungal species inhabiting feathers of living poultry birds (Gallus domesticus): A comparison. Mycopathologia 146(1):19-24. https://doi.org/10.1023/A:1007086720237

Kohn, L.M., and Stasovski, E. 1990. The mycorrhizal status of plants at Alexandra Fiord, Ellesmere Island, Canada, a High Arctic site. Mycologia 82(1):23 - 35. https://doi.org/10.1080/00275514.1990.12025836

Lawrence, E.B., Nelson, P.E., and Toussoun, T.A. 1985. Inheritance of compatibility and sex in Gibberella baccata. Phytopathology 75:322-324. https://doi.org/10.1094/Phyto-75-322

Lê, S., Josse, J., and Husson, F. 2008. FactoMineR: An R package for multivariate analysis. Journal of Statistical Software 25(1): $1-18$. https://doi.org/10.18637/jss.v025.i01

Libkind, D., Hittinger, C.T., Valério, E., Gonçalves, C., Dover, J., Johnston, M., Gonçalves, P., and Sampaio, J.P. 2011. Microbe domestication and the identification of the wild genetic stock of lager-brewing yeast. Proceedings of the National Academy of Science 108(35):14539-14544. https://doi.org/10.1073/pnas.1105430108
Limtong, S., Kaewwichian, R., Jindamorakot, S., Yongmanitchai, W., and Nakase, T. 2012. Candida wangnamkhiaoensis sp. nov., an anamorphic yeast species in the Hyphopichia clade isolated in Thailand. Antonie van Leeuwenhoek Journal of Microbiology 102(1):23-28. https://doi.org/10.1007/s10482-012-9709-Z

Liu, G., Zhang, L., Wei, X., Zou, G., Qin, Y., Ma, L., Li, J., et al. 2013. Genomic and secretomic analyses reveal unique features of the lignocellulolytic enzyme system of Penicillium decumbens. PLoS ONE 8: e55185. https://doi.org/10.1371/journal.pone.0055185

Luangsa-ard, J., Houbraken, J., van Doorn, T., Hong, S.-B., Borman, A.M., Hywel-Jones, N.L., and Samson, R.A. 2011. Purpureocillium, a new genus for the medically important Paecilomyces lilacinus. FEMS Microbiology Letters 321(2):141-149.

https://doi.org/10.1111/j.1574-6968.2011.02322.x

Ludley, K.E., and Robinson, C.H. 2008. 'Decomposer' Basidiomycota in Arctic and Antarctic ecosystems. Soil Biology and Biochemistry 40(1):11-29. https://doi.org/10.1016/j.soilbio.2007.07.023

Mallory, M.L., and Braune, B.M. 2012. Tracking contaminants in seabirds of Arctic Canada: Temporal and spatial insights. Marine Pollution Bulletin 64(7):1475-1484. https://doi.org/10.1016/j.marpolbul.2012.05.012

Mallory, M.L., Hatch, S.A., and Nettleship, D.N. 2012. Northern fulmar (Fulmarus glacialis). In: Poole, A., ed. The birds of North America Online, No. 361. Ithaca, New York: Cornell Lab of Ornithology. https://doi.org/10.2173/bna.361

Marcogliese, D.J. 2008. The impact of climate change on the parasites and infectious diseases of aquatic animals. Reviews in Science and Technology 27(2):467-484. https://doi.org/10.20506/rst.27.2.1820

Mašínová, T., Bahnmann, B.D., Větrovský, T., Tomšovský, M., Merunková, K., and Baldrian, P. 2017. Drivers of yeast community composition in the litter and soil of a temperate forest. FEMS Microbiology Ecology 93(2): fiw223. https://oi.org/10.1093/femsec/fiw223

Mbenoun, M., Garnas, J.R., Wingfield, M.J., Begoude Boyogueno, A.D., and Roux, J. 2017. Metacommunity analyses of Ceratocystidaceae fungi across heterogeneous African savanna landscapes. Fungal Ecology 28:76-85. https://doi.org/10.1016/j.funeco.2016.09.007

McRae, C.F., Hocking, A.D., and Seppelt, R.D. 1999. Penicillium species from terrestrial habitats in the Windmill Islands, East Antarctica, including a new species, Penicillium antarcticum. Polar Biology 21(1):97-111. https://doi.org/10.1007/s003000050340

Menkis, A., Marčiulynas, A., Gedminas, A., Lynikienė, J., and Povilaitienè, A. 2015. High-throughput sequencing reveals drastic changes in fungal communities in the phyllosphere of Norway spruce (Picea abies) following invasion of the spruce bud scale (Physokermes piceae). Microbiology Ecology 70(4):904-911. https://doi.org/10.1007/s00248-015-0638-z 
Mestre, M.C., Fontenla, S., and Rosa, C.A. 2014. Ecology of cultivable yeasts in pristine forests in northern Patagonia (Argentina) influenced by different environmental factors. Canadian Journal of Microbiology 60(6):371-382.

https://doi.org/10.1139/cjm-2013-0897

Miller, O.K., and Laursen, G.A. 1974. Belowground fungal biomass on U.S. tundra biome sites at Barrow, Alaska. In: Holding, A.J., Heal, O.W., MacLean, S.F., Jr., and Flanagan, P.W., eds. Soil organisms and decomposition in tundra. Stockholm Tundra Biome Steering Committee. 151-158.

Nikolajeva, V., Kḷava, D., and Kunkulberga, D. 2015. Evaluation of spoilage yeasts causing chalk mould defects on rye bread. Abstracts of the $73^{\text {rd }}$ Scientific Conference of the University of Latvia. Environmental and Experimental Biology 13(1): 50.

Okamoto, K., Imashiro, K., Akizawa, Y., Onimura, A., Yoneda, M., Nitta, Y., Maekawa, N., and Yanase, H. 2010. Production of ethanol by the white-rot basidiomycetes Peniophora cinerea and Trametes suaveolens. Biotechnology Letters 32(7):909-913. https://doi.org/10.1007/s10529-010-0243-7

Out, B., Boyle, S., and Cheeptham, N. 2016. Identification of fungi from soil in the Nakimu caves of Glacier National Park. Journal of Experimental Microbiology \& Immunology 2:26-32.

Park, M.S., Lee, E.J., Fong, J.J., Sohn, J.H., and Lim, Y.W. 2014. A new record of Penicillium antarcticum from marine environments in Korea. Mycobiology 42(2):109-113. https://doi.org/10.5941/MYCO.2014.42.2.109

Peris, D., Sylvester, K., Libkind, D., Gonçalves, P., Sampaio, J.P., Alexander, W.G., and Hittinger, C.T. 2014. Population structure and reticulate evolution of Saccharomyces eubayanus and its lager-brewing hybrids. Molecular Ecology 23(8):2031 - 2045. https://doi.org/10.1111/mec.12702

Piercey-Normore, M.D. 2005. Lichens from the Hudson Bay Lowlands: Northeastern coastal regions of Wapusk National Park in Manitoba. Canadian Journal of Botany 83(8):1029-1038.

https://doi.org/10.1139/b05-061

Pietikäinen, A., Kytöviita, M.-M., Husband, R., and Young, J.P.W. 2007. Diversity and persistence of arbuscular mycorrhizas in a low-Arctic meadow habitat. New Phytologist 176(3):691-698. https://doi.org/10.1111/j.1469-8137.2007.02209.x

Powell, A.N., and Suydam, R.S. 2012. King Eider (Somateria spectabilis), version 2.0. In: Rodewald, P.G., ed. The birds of North America. Ithaca, New York: Cornell Lab of Ornithology. https://doi.org/10.2173/bna.491

Provencher, J.F., Gilchrist, H.G., Mallory, M.L., Mitchell, G.W., and Forbes, M.R. 2016. Direct and indirect causes of sex differences in mercury concentrations and parasitic infections in a marine bird. Science of the Total Environment 551552:506-512.

https://doi.org/10.1016/j.scitotenv.2016.02.055

Pugh, G.J.F. 1965. Cellulolytic and keratinophilic fungi recorded on birds. Sabouraudia 4(2):85-91.

https://doi.org/10.1080/00362176685190221

R Core Team, 2015. R: A language and environment for statistical computing.

https://www.r-project.org
Rintala, H., Pitkäranta, M., and Täubel, M. 2012. Chapter 4 Microbial communities associated with house dust. In: Laskin, A.I., Sariaslani, S., and Gadd, G.M., eds. Advances in applied microbiology, Vol. 78. San Diego, California: Academic Press. $75-120$.

https://doi.org/10.1016/B978-0-12-394805-2.00004-X

Robinson, C.H. 2001. Cold adaptation in Arctic and Antarctic fungi. New Phytologist 151(2):341 - 353.

https://doi.org/10.1046/j.1469-8137.2001.00177.x

Santiago, I.F., Rosa, C.A., and Rosa, L.H. 2017. Endophytic symbiont yeasts associated with the Antarctic angiosperms Deschampsia antarctica and Colobanthus quitensis. Polar Biology 40(1):177-183.

https://doi.org/10.1007/s00300-016-1940-z

Schoch, C.L., Seifert, K.A., Huhndorf, S., Robert, V., Spouge, J.L., Levesque, C.A., Chen, W., and Fungal Barcoding Consortium. 2012. Nuclear ribosomal internal transcribed spacer (ITS) region as a universal DNA barcode marker for fungi. Proceedings of the National Academy of Sciences 109(16):6241-6246.

https://doi.org/10.1073/pnas.1117018109

Schubert, K., Groenewald, J.Z., Braun, U., Dijksterhuis, J., Starink, M., Hill, C.F., Zalar, P., de Hoog, G.S., and Crous, P.W. 2007. Biodiversity in the Cladosporium herbarum complex (Davidiellaceae, Capnodiales), with standardisation of methods for Cladosporium taxonomy and diagnostics. Studies in Mycology 58:105-156.

https://doi.org/10.3114/sim.2007.58.05

Scott, J.A., and Untereiner, W.A. 2004. Determination of keratin degradation by fungi using keratin azure. Medical Mycology 42(3):239-246.

https://doi.org/10.1080/13693780310001644680

Singh, P., and Singh, S.M. 2012. Characterization of yeast and filamentous fungi isolated from cryoconite holes of Svalbard, Arctic. Polar Biology 35(4):575-583.

https://doi.org/10.1007/s00300-011-1103-1

Singh, S.M., Tsuji, M., Gawas-Sakhalker, P., Loonen, M.J.J.E., and Hoshino, T. 2016. Bird feather fungi from Svalbard Arctic. Polar Biology 39(3):523-532. https://doi.org/10.1007/s00300-015-1804-y

Sonjak, S., Frisvad, J.C., and Gunde-Cimerman, N. 2006. Penicillium mycobiota in Arctic subglacial ice. Microbiology Ecology 52(2):207-216.

https://doi.org/10.1007/s00248-006-9086-0

Sun, X., Liu, Z., Qu, Y., and Li, X. 2008. The effects of wheat bran composition on the production of biomass-hydrolyzing enzymes by Penicillium decumbens. Applied Biochemistry and Biotechnology 146(1-3):119-128.

https://doi.org/10.1007/s12010-007-8049-3

Tamura, K., Stecher, G., Peterson, D., Filipski, A., and Kumar, S. 2013. MEGA6: Molecular evolutionary genetics analysis Version 6.0. Molecular Biology and Evolution 30(12):2725-2729.

https://doi.org/10.1093/molbev/mst197

Tosi, S., Casado, B., Gerdol, R., and Caretta, G. 2002. Fungi isolated from Antarctic mosses. Polar Biology 25(4):262-268. https://doi.org/10.1007/s00300-001-0337-8 
Tsuji, M., Tanabe, Y., Vincent, W.F., and Uchida, M. 2018a. Gelidatrema psychrophila sp. nov., a novel yeast species isolated from an ice island in the Canadian High Arctic. Mycoscience 59(1):67-70.

https://doi.org/10.1016/j.myc.2017.08.010

___ 2018b. Mrakia arctica sp. nov., a new psychrophilic yeast isolated from an ice island in the Canadian High Arctic. Mycoscience 59(1):54-58.

https://doi.org/10.1016/j.myc.2017.08.006

Van der Putten, W.H., Macel, M., and Visser, M.E. 2010. Predicting species distribution and abundance responses to climate change: Why it is essential to include biotic interactions across trophic levels. Philosophical Transactions of the Royal Society B, Biological Sciences 365(1549):2025-2034. https://doi.org/10.1098/rstb.2010.0037

Visagie, C.M., and Jacobs, K. 2012. Three new additions to the genus Talaromyces isolated from Atlantis sandveld fynbos soils. Persoonia - Molecular Phylogeny and Evolution of Fungi 28:14-24. https://doi.org/10.3767/003158512X632455

Weiser, E., and Gilchrist, H.G. 2012. Glaucous gull (Larus hyperboreus), version 2.0. In: Rodewald, P.G., ed. The birds of North America. Ithaca, New York: Cornell Lab of Ornithology. https://doi.org/10.2173/bna.573

White, T.J., Bruns, T., Lee, S., and Taylor, J. 1990. Amplification and direct sequencing of fungal ribosomal RNA genes for phylogenetics. In: Innis, M.A., Gelfand, D.H., Sninsky, J.J., and White, T.J. PCR protocols: A guide to methods and applications. San Diego, California: Academic Press. 315-322. https://doi.org/10.1016/B978-0-12-372180-8.50042-1

Wickham, H. 2009. ggplot2: Elegant graphics for data analysis. New York: Springer Science+Business Media. https://doi.org/10.1007/978-0-387-98141-3
Widden, P., and Parkinson, D. 1979. Populations of fungi in a High Arctic ecosystem. Canadian Journal of Botany 57(21):2408-2417. https://doi.org/10.1139/b79-284

Wilken, E., Jiménez Nava, F., and Griffith, G. 2011. North American terrestrial ecoregions - Level III. Montreal, Quebec: Commission for Environmental Cooperation.

Wojczulanis-Jakubas, K., Dynowska, M., and Jakubas, D. 2011. Fungi prevalence in breeding pairs of a monogamous seabird - Little Auk, Alle alle. Ethology Ecology \& Evolution 23(3):240-247. https://doi.org/10.1080/03949370.2011.566582

Yilmaz, N., Visagie, C.M., Houbraken, J., Frisvad, J.C., and Samson, R.A. 2014. Polyphasic taxonomy of the genus Talaromyces. Studies in Mycology 78:175-341. https://doi.org/10.1016/j.simyco.2014.08.001

Zalar, P., de Hoog, G.S., Schroers, H.-J., Crous, P.W., Groenewald, J.Z., and Gunde-Cimerman, N. 2007. Phylogeny and ecology of the ubiquitous saprobe Cladosporium sphaerospermum, with descriptions of seven new species from hypersaline environments. Studies in Mycology 58:157-183. https://doi.org/10.3114/sim.2007.58.06

Zhang, X., Tang, G., Xu, X., Nong, X., and Qi, S.-H. 2014. Insights into deep-sea sediment fungal communities from the East Indian Ocean using targeted environmental sequencing combined with traditional cultivation. PLoS ONE 9(10): e109118. https://doi.org/10.1371/journal.pone.0109118

Zhang, Y.-J., Huo, L.-Q., Zhang, S., and Liu, X.-Z. 2016. The complete mitochondrial genome of the cold-adapted fungus Pseudogymnoascus pannorum syn. Geomyces pannorum. Mitochondrial DNA Part A 27(4):2566-2567. https://doi.org/10.3109/19401736.2015.1038806 